Care: Jurnal Ilmiah Ilmu Kesehatan Vol .8, No.2, 2020, hal 195-205

Tersedia online di https://jurnal.unitri.ac.id/index.php/care

ISSN 2527-8487 (online)

ISSN 2089-4503 (cetak)

\title{
EFIKASI EKSTRAK DAUN ZODIA (Evodia suaveolens) PELARUT HEKSANA DALAM MEMATIKAN LARVA INSTAR III Aedes aegypti
}

\author{
Didi Setiyadi ${ }^{1)}$, Martini $^{2)}$, Mochamad Hadi ${ }^{3)}$ \\ ${ }^{1)}$ Magister Epidemiologi, Universitas Diponegoro, Semarang, Indonesia \\ ${ }^{2)}$ Fakultas Kesehatan Masyarakat, Universitas Diponegoro, Semarang, Indonesia \\ ${ }^{3)}$ Fakultas Sains dan Matematika, Universitas Diponegoro, Semarang, Indonesia \\ E-mail: didisetiyadi@,outlook.co.id; didisetiyadi1@live.com
}

\begin{abstract}
DHF is a disease caused by a virus which is transmitted through the bite of the Aedes aegypti mosquito and is one of the bealth problems in Indonesia. Efforts to decide the transmission of DHF by controlling the population of Aedes aegypti at the larval stage using larvaside temepos. Long-term use of temephos causes Aedes aegypti resistance and environmental damage. One of the plants that has the potential as botanical larvaside is

the leaves of zodia (Evodia suaveolens). The purpose of this study was to prove the efficacy of zodia leaves of hexane solvent for killing $A$. aegypti larvae. This type of research is a pure experiment with the post test only control group design. The research sample is A. aegypti stage III susceptible strain. There are 7 groups consisting of 1 negative control (aquades), positive control (1 ppm temepos) and 5 treatment groups (zodia leaf extract). Data on larval mortality were counted 24 bours after treatment. The results of the one way ANOVA test showed that there were differences in mortality between test groups with a $p$ value: $0.001 \mathrm{a}$ (0.05). Zodia leaf extract probit test results showed $L C_{50}-24$ bour and $L C_{90}-24$ bour values of 0,443 ppm and 0,788 ppm. Zodia leaf extract with hexane solvent has efficacy as Aedes aegypti larvicide.
\end{abstract}

Keywords: Aedes aegypti; Evodia suaveolens; larvacide; zodia extract; zodia leaves.

\begin{abstract}
ABSTRAK
DBD merupakan penyakit yang disebabkan virus yang penularannya melalui gigitan nyamuk Aedes aegypti dan menjadi salah satu masalah kesehatan di Indonesia. Upaya memutuskan penularan DBD dengan mengendalikan populasi Aedes aegypti pada tahap larva menggunakan larvasida temepos. Pengunaan temepos jangka panjang menyebabkan resistensi Aedes aegypti dan kerusakan lingkungan. Salah satu tanaman yang berpotensi sebagai larvasida botani adalah
\end{abstract}

Cara mengutip: Setiyadi, Didi., Martini, \& Hadi, Mochamad. (2020). Efikasi Ekstrak Daun Zodia (Evodia suaveolens) Pelarut Heksana Dalam Mematikan Larva Instar III Aedes aegypti. Care:Jurnal Ilmiah Ilmu Kesehatan, 8(2), 195-205

Retrieved from https://jurnal.unitri.ac.id/index.php/care/article/view/1675 
daun zodia (Evodia suaveolens). Tujuan penelitian adalahmembuktikan efikasi daun zodiapelarut heksana untuk mematikan larva $A$. aegypti. Jenis penelitian ini adalah eksperimen murni dengan desain post test only control group design. Sampel penelitian merupakan $A$. aegypti instar III susceptible strain. Terdapat 7 kelompok yang terdiri dari 1 kontrol negatif (aquades), kontrol positif (temepos $1 \mathrm{ppm}$ ) dan 5 kelompok perlakuan (ekstrak daun zodia). Data kematian larva dihitung selama 24 jam setelah perlakuan. Hasil uji one way $A N O V A$ menunjukkan terdapat perbedaan kematian antarkelompok uji dengan nilai p: $0,001 \leq \alpha(0,05)$. Hasil uji probit ekstrak daun zodiamenunjukkan nilai $\mathrm{LC}_{50}-24$ jam dan $\mathrm{LC}_{90}-24$ jam yaitu $0,443 \mathrm{ppm}$ dan 0,788 ppm. Ekstrak daun zodiadengan pelarut heksana memiliki efikasi sebagai larvasida Aedes aegypti.

Kata Kunci : Aedes aegypti; daun zodia; ekstrak zodia; Evodia suaveolens; larvasida.

\section{PENDAHULUAN}

Demam Berdarah Dengue (DBD) adalah penyakit yang disebabkan virus dari golongan flaviviridae yang ditularkan oleh Aedes aegypti dan Aedes albopictus (WHO, 2020).Sebuah studi permodelan menunjukkan risiko infeksi DBD terjadi di 129 negara dan terdapat \pm 390 juta infeksi pada manusia setiap tahunnya(Bhatt et al, 2013). DBD di Indonesia tahun 2016, Insiden Rate (IR) 78,85 per 100.000 penduduk; Case Fatality Rate (CFR) 0,78\%. Tahun 2017, IR 26,10 per 100.000 penduduk; CFR 0,72\%. Tahun 2018, IR 24,75 per 100.000 penduduk; CFR 0,71\%. Meskipun terjadi penurunan IR dan CFR dari tahun 2016 - 2018 di Indonesia, namun DBD merupakan penyebab kematian utama pada kelompok usia sekolah dan masih menjadi prioritas pengendalian penyakit menular Kementerian Kesehatan Republik Indonesia (Kemenkes RI, 2013, 2018).
Upaya pemutusan penularan penyakit DBD dilakukan dengan cara mengendalikan populasi $A$. aegypti. Pengendalian $A$. aegypti yang paling mudah, praktis dan umum dilakukan masyarakat adalah saat berada stadium larva dengan menggunakan larvasida temepos (WHO, 2011). Sejak tahun 1980 sampai saat ini temepos 1\% (Abate) merupakan jenis larvasida pilihan utama untuk mengendalikan larva $A$. aegypti di Indonesia (FuadzyH. dkk, 2015). Penggunaan temepos secara berulang-ulang dan dalam jangka panjang menimbulkan masalah lain seperti resistensi, kebangkitan spesies hama, pencemaran lingkungan, bahaya racun bagi manuisa dan organisme non target (Ridha dkk, 2011). Penelitian di Kota Banjarbaru, Kota Surabaya dan Kota Semarang menunjukkan terdapat indikasi resisten terhadap temepos pada larva $A$. aegypti (Handayani dkk, 2016; Mulyatno et al, 2012; Ridha \& Nisa, 2011). Banyaknya 
Care: Jurnal Ilmiah Ilmu Kesehatan Vol .8, No.2, 2020, hal 195-205

dampak negatif penggunaan larvasida sintetis mendorong untuk penelitian mengenai larvasida botani.(Nurhaifah, D.\& Sukesi, T.W. 2015)

Salah satunya tanaman yang berpotensi sebagai larvasida botani adalah tanaman zodia (Evodia suaveolens). Berdasarkan hasil skrining fitokimia menunjukkan daun zodia memiliki efek sebagai insektisida dan larvasida yaitu alkaloid, tanin, saponin dan flavanoid (Lestari dkk, 2015). Penelitian lain membuktikan ekstrak daun zodiadengan pelarut etanol 70\% memiliki kemampuan sebagai larvasida $A$. aegypti strain rentan dan strainKecamatan Tembalang(Basundari, S.A. dkk, 2018; Handayani, S.W. dkk, 2017).

Dari beberapa penelitian di atas, menunjukkan ekstrak daun zodia sebagai larvasida menggunakan pelarut etanol 70\% yang bersifat polar. Pelarut bersifat polar memiliki kemampuan untuk melarutkan senyawa-senyawa polar, namun tidak dapat melarutkan senyawa non polar. Uji ekstrak jeruk purut sebagai larvasida menunjukkan ekstrak dengan pelarut heksana (pelarut non polar) memilliki daya bunuh lebih baik terhadap larva $A$. aegypti dibandingkan ekstrak dengan pelarut metanol (pelarut polar) (Nur dkk, 2015). Berdasarkan uraian tersebut penelitian dilakukan untuk membuktikan efikasi daun zodiadengan heksana (pelarut non polar) untuk mematikan larva $A$. aegypti.

\section{METODE PENELITIAN}

Jenis penelitian ini adalah eksperimen murni dengan post test only control group design. Uji larvasida dilaksanakan pada bulan Agustus sampai November 2019 di Laboratorium Pestisida Botani B2P2VRP Salatiga. Bahan yang digunakan saat pengujian adalah aquades, ekstrak daun zodiadan $A$. aegypti instar IIIstrain rentan. Alat yang digunakan saat pengujian adalah gelas, neraca analitik, kolok, termometer, hygrometer, $\mathrm{pH}$ meter, arloji, gelas ukur, pipet volume, cawan petri, ciduk jentik dan tisu.

Daun zodia berasal dari Taman B2P2VRP Salatiga. Daun dicuci sampai bersih dengan menggunakan air, kemudian dikeringkan dengan cara dijemur pada tempat yang tidak terpapar matahari secara langsung selama 120 jam. Setelah kering dilanjutkan memotong menjadi kecil dengan menggunakan blender;menimbang simplisia dan pelarut heksana dengan perbandingan 1:3 dan dilakukan perendaman selama 72 jam. Campuran simplisia dan heksana disaring dengan menggunakan kertas saring. 
Penguapan ekstrak pada rotary evaporator pada suhu $60 \quad{ }^{0} \mathrm{C}$ (Harbone, 1987). Pembuatan ekstrak dilakukan di Laboratorium Teknologi Pangan UNIKA Semarang.

Mengacu pada ketentuan WHO, sampel yang digunakan adalah $A$. aegypti instar III strain rentan sebanyak 25 ekor pada setiap kelompok (WHO, 2005). Terdapat 7 kelompok yang terbagi menjadi 1 kelompok kontrol negatif (aquades), 1 kelompok positif (temepos konsentrasi 1 ppm) dan 5 kelompok perlakuan (ekstrak zodia pelarut heksana konsentrasi 0,2 ppm, 0,4 ppm, 0,6 ppm, 0,8 ppm dan 1 ppm). Pengulangan dilakukan sebanyak 4 kali yang ditentukan melalui perhitungan rumus Federer. Jumlah sampel yang digunakan saat pengujian sebesar 700 A. aegypti instar IIIstrain rentan. Kriteria inklusi yang ditetapkan adalah $A$. aegypti instar III strain rentan yang bergerak aktif dan kriteria eksklusi yang ditetapkan adalah larva $A$. aegypti cacat atau mati sebelum perlakuan. Data kematian $A$. aegypti instar III strain rentan dicatat pada 6 jam, 12 jam, 18 jam dan 24 jam setelah perlakuan.

Persentase kematian kontrol positif dan kelompok perlakuan dikoreksi menggunakan rumus Abbot jika persentase kematian larva pada kelompok kontrol negatif berada antara $\geq 5 \%$ sampai $<20 \%$ (WHO, 2005). Data kematian larva $A$. aegypti dianalisis menggunakan uji One $W$ ay ANOVA untuk membuktikan bahwa terdapat perbedaan rerata kematian antarkelompok uji. Analisis Probit dilakukan untuk mengetahui nilai $\mathrm{LC}_{50}-24$ jamdan $\mathrm{LC}_{90}-24$ jam. Perangkat lunak yang digunakan untuk analisis adalah IBM SPSS for windows versi 22.

\section{HASIL}

Tabel 1. Hasil pengukuran variabel lingkungan pada uji ekstak daun zodia dalam membunuh larva $A$. aegypti

\begin{tabular}{lcccc}
\hline Parameter & Min. & \multicolumn{3}{c}{ Max. } \\
\cline { 2 - 5 } & Awal & Akhir & Awal & Akhir \\
Suhu air & $26,6^{\circ} \mathrm{C}$ & $26,2^{\circ} \mathrm{C}$ & $26,9^{\circ} \mathrm{C}$ & $26,8^{\circ} \mathrm{C}$ \\
Suhu ruangan & $27,2^{\circ} \mathrm{C}$ & $27,3^{\circ} \mathrm{C}$ & $27,2^{\circ} \mathrm{C}$ & $27,3^{\circ} \mathrm{C}$ \\
pH air & 3,54 & 3,59 & 4,64 & 5,08 \\
Kelembapan & $80^{\circ} \%$ & $77 \%$ & $80^{\circ} \%$ & $77 \%$ \\
\hline
\end{tabular}


Care: Jurnal Ilmiah Ilmu Kesehatan Vol .8, No.2, 2020, hal 195-205

Tabel 1. memberikan informasi bahwa suhu air dan suhu ruangan secara berurutan antara $26^{\circ} \mathrm{C}$ sampai $27^{\circ} \mathrm{C}$ yang diukur saat awal dan akhir pengujian. Pengukuran $\mathrm{pH}$ air berada antara3,54 sampai 5,08 yang menunjukkan bahwa aquades saat pengujian berlangsung bersifat asam. Pengukuran terhadap kelembapanudara saat pengujian berlangsung antara 77\% sampai 80\%.

Tabel 2. memberikan informasi bahwan mortalitas larva $A$. aegypti pada kelompok kontrol negatif sebesar 7\%pada pengamatan ke 24 jam. Mengikuti ketentuan WHO dalam pengujian larvasida, maka persentase kelompok kontrol positif dan kelompok perlakuan dikoreksi menggunakan rumus Abbot.Pada kelompok kontrol positif (temepos konsentrasi $1 \mathrm{ppm}$ ) dan ekstrak zodia konsentrasi 1 ppm mampu menyebabkan kematian sebesar 100\% larva A. aegypti pada pengamatan ke 24 jam. Hasil uji One Way $A N O V A$ menunjukkan terdapat perbedaan rerata kematian larva $A$. aegypti antar kelompok yang bermakna secara statistik dengan nilai p: 0,001.

Tabel 2. Pengaruh ekstrak daun zodia terhadap jumlah kematian larva $A$. aegypti mati pada pengamatan 24 jam

\begin{tabular}{lccccccccc}
\hline Kelompok & n & \multicolumn{9}{c}{ Jumlah larva A. aegypti mati } & & & p \\
\cline { 3 - 10 } & & R I & R II & R III & R IV & $\Sigma$ & X & $\%^{*}$ & $0,001^{* *}$ \\
Kontrol - & 25 & 0 & 3 & 4 & 0 & 7 & 1,25 & 7,00 & \\
Kontrol + & 25 & 25 & 25 & 25 & 25 & 100 & 25,00 & 100,0 & \\
$\mathbf{0 , 2}$ ppm & 25 & 3 & 1 & 5 & 2 & 11 & 2.75 & 4,300 & \\
$\mathbf{0 , 4}$ ppm & 25 & 7 & 5 & 11 & 6 & 29 & 7.25 & 23,05 & \\
$\mathbf{0 , 6}$ ppm & 25 & 19 & 20 & 19 & 17 & 75 & 18.75 & 73,11 & \\
$\mathbf{0 , 8}$ ppm & 25 & 20 & 24 & 23 & 25 & 92 & 23,00 & 91,39 & \\
$\mathbf{1}$ ppm & 25 & 25 & 25 & 25 & 25 & 100 & 25,00 & 100,0 & \\
\hline
\end{tabular}

\section{Keterangan:}

$\mathrm{R}=$ Replikasi

$\%^{*}=$ Persentase kematian larva $A$. aegyptisetelah dikoreksi menggunakan rumus Abbo

** = Signifikan berdasarkan uji One Way ANOVA $\mathrm{p} \leq \alpha(0,05)$ 


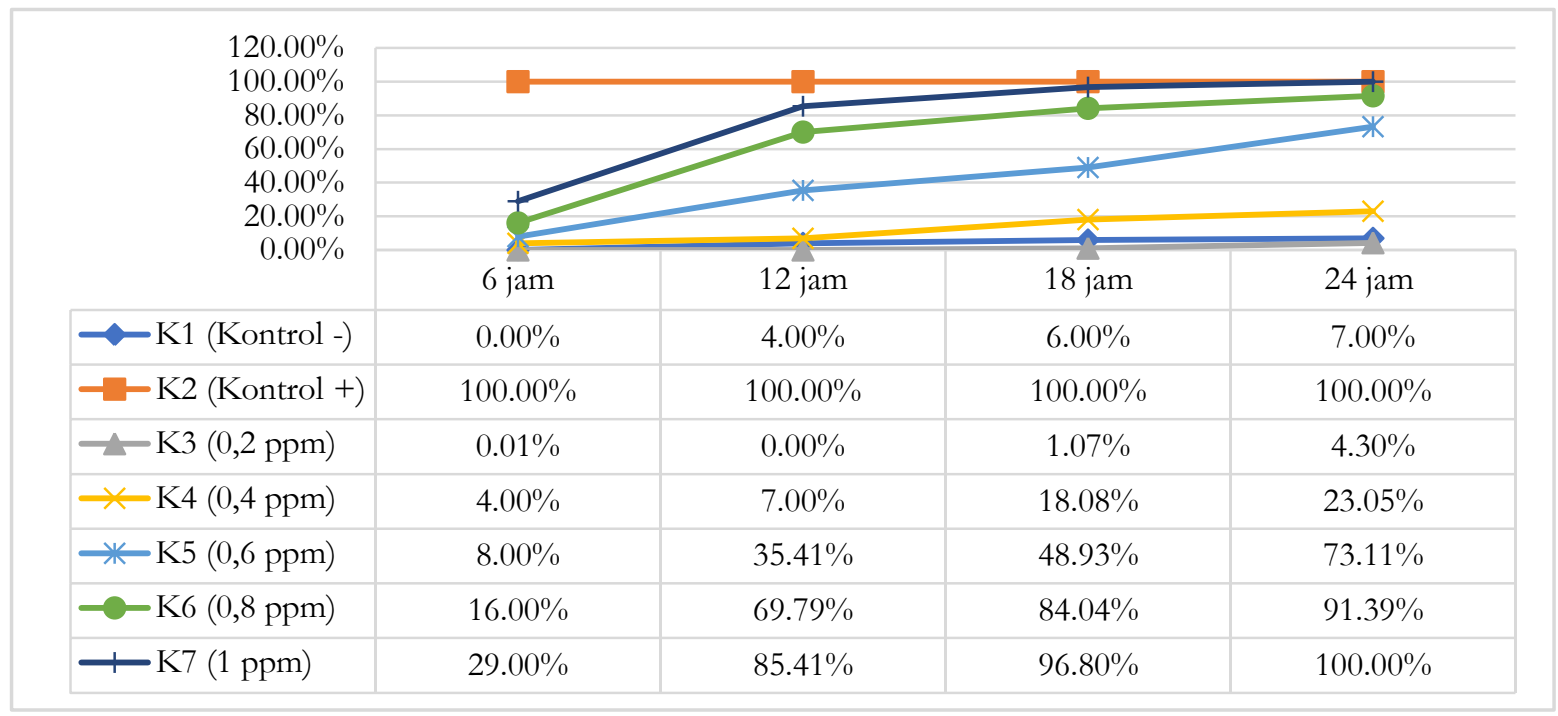

Gambar 1. Pengaruh ekstrak daun zodiaterhadap kematianlarva $A$. aegypti berdasarkan waktu

Gambar 1. memberikan informasi bahwa pada kontrol positif (temepos konsentrasi 1 ppm) mampu menyebabkan mortalitas $100 \%$ larva $A$. aegypti pada pengamatan ke 6 jam dibandingkan dengan kelompok ekstrak zodia konsentrasi 1 ppm mampu menyebabkan kematian 100\% pada waktu pengamatan ke 24 jam. Secara umum juga memberikan informasi semakin lama waktu paparan ekstrak daun zodia meningkatkan persentase kematian larva $A$. aegypti.

Berdasarkan Tabel 3. memberikan informasi bahwa konsentrasi ekstrak daun zodia menyebabkan kematian 50\% dan 90\% larva $A$. aegypti waktu pengamatan 24 jamyaitu sebesar 0,443 ppm dan 0,788 ppm.

Tabel 3.Nilai $\mathrm{LC}_{50}-24$ jam dan $\mathrm{LC}_{95}-24$ jam ekstrak daun zodiaterhadap kematianlarva $A$. aegypti

\begin{tabular}{lcc}
\hline Analisis probit & $\begin{array}{c}\text { Konsentrasi } \\
(\mathbf{p p m})\end{array}$ & $\begin{array}{c}\text { Konsentrasi batas atas dan batas bawah } \\
(\mathbf{p p m})\end{array}$ \\
\hline $\mathbf{L C}_{\mathbf{5 0}} \mathbf{2} \mathbf{2 4}$ jam & 0,433 & $0,370-0,494$ \\
$\mathbf{L C}_{\mathbf{9 0}} \mathbf{2} \mathbf{2 4}$ jam & 0,788 & $0,672-1,003$ \\
\hline
\end{tabular}


Care: Jurnal Ilmiah Ilmu Kesehatan Vol .8, No.2, 2020, hal 195-205

\section{PEMBAHASAN}

Kematian larva $A$. aegypti pada kelompok kontrol negatif (aquades) pada pengamatan ke 24 jam sebesar 7\% (Tabel 2). Hal ini membuktikan bahwa terdapat faktor lingkungan yang berpengaruh yaitu $\mathrm{pH}$ aquades antara 3,54 sampai 4,87 yang artinya aquades bersifat asam (Tabel 1.). Penelitian Hijjarahwati dkk membuktikan bahwa $\mathrm{pH}$ air antara 3 sampai 5 menyebabkan kematian pada larva $A$. aegypti (Hijjarahwati dkk, 2018). Berbeda dengan Ridha menunjukkan bahwa larva $A$. aegypti mampu hidup di alam pada $\mathrm{pH}$ air antara 3 sampai dengan 12 (M. Ridha dkk, 2013). pH air yang bersifat asam menyebabkan gangguan pernapasan larva melalui penurunan kemampuan enzim sitokrom oksidase dan menyebabkan kematian pada plakton, yang merupakan sumber makanan bagi larva A. aegypti ( Hijjarahwati dkk, 2018). Persentase kematian larva pada kelompok kontrol positif (temepos konsentrasi 1 ppm) dan kelompok perlakuan (ekstrak zodia) dikoreksi menggunakan rumus Abbot, koreksi tersebut dilakukan untuk mendapatkan gambaran kemampuan ekstrak zodia untuk mematikan larva $A$. aegypti yang lebih proporsional dan presisi; yang pada pengujian ini terdapat pengaruh $\mathrm{pH}$ asam (aquades) yang mempengaruhi kematian larva A. aegypti (Finney, 1952).

Hasil pengujian membuktikanpeningkatan konsentrasi dan lama waktu paparan ekstrak zodia pelarut heksanan (non polar) diikuti peningkatan persentase kematian larva $A$. aegypti (Tabel 2 dan Gambar 1). Hasil uji one way $A N O V A$ membuktikan bahwa terdapat perbedaan rerata kematian larva antarkelompok bermakna secara statistik (Tabel 2). Hal ini menunjukkan bahwa kematian larva $A$. aegypti disebabkan pemberian ekstrak daun zodia.Sesuai dengan penelitian Handayani dkk menunjukkan ekstrak zodia pelarut etanol $70 \%$ (polar) mampu menyebabkan kematian pada larva $A$. aegypti(Handayani, S.W. dkk, 2015). Hasil penelitian Basundari dkk juga membuktikan ekstrak daun zodia pelarut etanol 70\% (polar) mampu menyebabkan kematian pada larva $A$. aegyptistrain Kecamatan Tembalang(Basundari S.A. dkk, 2018). Penyebab kematian larva A. aegypti pada kelompok perlakuan dapat dikaitkan kandungan metabolit sekunder yang mempengaruhi pertumbuhan dan perkembangan larva. Kandungan metabolit sekunder daun zodiayang memililiki efek sebagai larvasida oleh antara lain alkaloid, tanin, saponin dan flavanoid(Basundari, 
S.W.dkk, 2018; Lestari M.S. dkk, 2015). Alkaloid berfungsi sebagai racun perut dengan cara menganggu kerja enzim asetil kolinesterase yang memiliki tugas meneruskan perintah ke saluran pencernaan larva sehingga gerakan tidak dapat terkendali. Ciri-ciri larva yang mati yang disebabkan oleh alkaloid adalah gerakan naik pada permukaan air, warna lebih transparan, gerakan tubuh larva lambat dan selalu membengkokkan badan(Ahdiyah, I,\& Purwani, K.I.,2015). Tanin yang masuk melalui saluran perncernaan menyebabkan gangguan penyerapan protein melalui aktivitas enzim pencernaan dan penyerapan makanan. Saponin menyebabkan kerusakan membran kutikula, merusak membran sel, menurunkan nafsu makan dan mengiritasi saluran pencernaan sehingga mengganggu pertumbuhan dan perkembangan larva.(Arts H.P.T\& College, R.Y.K.S. 2014; Pilla et al, 2012) Kandungan senyawa flavonoid masuk melalui ke tubuh larva melalui siphon dan menyebabkan kerusakan pernafasan. Perubahan perilaku larva berupa gerakan dan respon larva lambat,tubuh larva sejajar dengan permukaan air; posisi tersebut memudahkan larva untuk mengambil oksigen.
Konsentrasi yang dibutuhkan ekstrak daun zodia pelarut heksana (non polar) untuk menyebabkan kematian 50\% dan 90\% larva uji dalam waktu 24 jam adalah 0,433 ppm dan 0,788 ppm (Tabel 3). Berdasarkan nilai $\mathrm{LC}_{50}$ dengan menggunakan yang klasifikasi sitotoksik dibuat Mayer dikategorikan ekstrak yang bersifat toksik. (Meyer et al, 1982).Penelitian Handayani dkk menunjukkan konsentrasi ekstrak daun zodia pelarut etanol 70\% (polar) mampu menyebabkan kematian sebesar $50 \%$ dan 90\% dalam waktu 24 jam adalah 1,94 ppm dan 6,28 ppm (Handayani,S.W. dkk, 2017). Penelitian Basundari dkk mengenai ekstrak daun zodia pelarut etanol $70 \%$ (polar) sebagai larvasida $A$. aegypti strain Kecamatan Tembalang memiliki nilai $\mathrm{LC}_{50}-72$ jam (Basundari S.A.dkk, 2018). Hal ini memberikan informasi bahwa ekstrak daun zodia menggunakan pelarut non polar membutuhkan ekstrak lebih sedikit dibandingkan ekstrak dengan pelarut polar untuk menyebabkan kematian larva uji. Sesuai dengan penelitian Nur et al menunjukkan ekstrak jeruk purut (Citrus bystrix) pelarut heksana (non polar) memiliki nilai $\mathrm{LC}_{90}$ memiliki nilai lebih kecil dibandingkan dengan ekstrak jeruk purut pelarut metanol (polar) (Nur, A.et al, 2015). Berbeda dengan penelitian Yuliasih, daya 
Care: Jurnal Ilmiah Ilmu Kesehatan Vol .8, No.2, 2020, hal 195-205

bunuh biji kayu besi pantai (Pongamia pinnata) dengan pelarut metanol (polar) dan kloroform (non polar) terhadap larva $A$. aegypti menunjukkan nilai $\mathrm{LC}_{50}$ lebih kecil pada pelarut polar dibandingkan pelarut polar.(Yuliasih \& Widawati, 2018). Berdasarkan beberapa penelitian di atas, perbedaan kemampuan daya bunuh ekstrak pada larva $A$. aegypti disebabkan oleh spesies tanaman, strain larva nyamuk dan pelarut. Selain tersebut, ada faktor lain yang dapat mempengaruhi efikasi esktrak sebagai larvasida adalah mutu ekstrak. Menurut Kemenkes RI terdapat faktor-faktor mempengaruhi mutu antara lain identitas jenis, lokasi tumbuh asal (musim, sinar matahari, ketinggian, curah hujan), periode pemanenan hasil tumbuhan, penyimpanan bahan tumbuhan, umur, bagian tumbuhan, komposisi kualitatif, kuantitatif senyawa, metode ekstraksi, ukuran bahan, kekerasan bahan dan kekeringan bahan (Depkes RI, 2000).

\section{KESIMPULAN}

Ekstrak daun zodiapelarut heksana memiliki efikasi larvasida $A$. aegypti. Nilai $\mathrm{LC}_{50}-24$ jam dan $\mathrm{LC}_{90}-24$ jam ekstrak daun zodia pelarut heksanasebagai larvasida sebesar 0,443 ppm dan 0,788 ppm. Perlu dilakukan pengaruh sifat $\mathrm{pH}$ terhadap efikasi ekstrak zodia heksana sebagai larvasida dan uji fitokimia (TLC, UV-VIS dan Mass sepktrometri) untuk mengetahui kandungan senyawa kimia ekstrak zodiapelarut heksana.

\section{UCAPAN TERIMA KASIH}

Disampaikan terima kasih kepada B2P2VRP Salatiga, Laboratorium Teknologi Pangan UNIKA Semarang atas izin dan dukungan dalam menjalankan penelitian ini serta semua pihak yang berkontribusi dalam penelitian ini.

\section{REFERENSI}

Ahdiyah, I.\& Purwani, K.I. (2015). Pengaruh Ekstrak Daun Mangkokan (Nothopanax scutellarium) sebagai Larvasida Nyamuk Culex sp.Jurnal Sains Dan Seni ITS, 4:2

Arts, H.P.T. \& College, R.Y.K.S. (2014). Larvicidal Activity of Some Saponin Containing Plants Against the Dengue Vector Aedes Aegypti. JournalTrends in Biotechnology Research,3:1

Basundari, S.A. dkk (2018). Pengaruh Kandungan Ekstrak Daun Zodia (Evodia suaveolens) terhadap Mortalitas Larva Nyamuk Aedes aegypti. Berkala Ilmiah Biologi, 20:1

Bhatt, S.et al (2013). The Global Distribution and Burden of Dengue. HHS Public Access, 496:7446, 504-507.

Depkes RI. (2000) Parameter Standar Umum Ekstrak Tumbuban Obat. $1^{\text {st }}$ ed. Jakarta. 12-13.

Finney, D.J. (1925)Probit analysis:Adjustments for Natural Mortality. $2^{\text {nd }}$ ed. London Cambridge University Press,88-91.

Fuadzy, H. dkk (2015). Kerentanan Larva 
Aedes aegypti Terhadap Temefos di Tiga Kelurahan Endemis Demam Berdarah Dengue Kota Sukabumi. Buletin Penelitian Kesehatan, 43:1 41-46.

Handayani, N.(2016). Status Resistensi Larva Aedes Aegypti terhadap Temephos di Wilayah Perimeter dan Buffer Pelabuhan Tanjung Emas Kota Semarang. Jurnal Kesehatan Masyarakat, $4: 3$

Handayani, S.W.(2017). Potensi Umbi Gadung (Dioscorea hispida) dan Daun Zodia (Euodia suaveolens) sebagai Insektisida Nabati. Media Penelitian Dan Pengembangan Kesehatan, 27:1 49-56.

Harbone, J. B. (1987). Metode Fitokimia Penuntun Cara Modern Menganalisis Tumbuhan. Bandung: ITB.

Hijjarahwati dkk (2018). Pengaruh Variasi Derajat Keaasaman $(\mathrm{pH})$ Air Terhadap Pertumbuhan Larva Aedes sp. Universitas Muhammadiyah Semarang. Retrieved from : http://repository.uni mus.ac.id/id/eprint/2899

KemenkesRI. (2013). Rencana Strategis Kementrian Kesehatan Tabun 2015-2019. Jakarta: Kementerian Kesehatan RI.

Kemenkes RI. (2018). Profil Kesehatan Indonesia Tabun 2018.Jakarta.Kementerian Kesehatan RI.

Lestari,M.S.(2015). Toxicity and phytochemistry test of methanol extract of several plants from papua using Brine Shrimp Lethality Test (BSLT). Journal of Chemical and Pharmacentical Research, 7:4, 866-872

Meyer, B.N.et al (1982). Brine shrimp: A convenient general bioassay for active plant constituents. Planta Medica, 45:1, 31-34.

Mulyatno, K.C. dkk (2012). Resistance of Aedes aegypti (L.) Larvae to Temephos in Surabaya, Indonesia. The Southeast Asian Journal of Tropical Medicine and Public Health, 43:1, 29-33.
Nur, A.et al. Biolarvicidal Effectivities of Polar and Non-polar Extract Fraction from Kaffir Lime (Citrus bystrix) Leaf against 3rd Instar Larvae of Aedes aegypti. Journal of Biological Engineering Research and Review11: 13-17.

Nurhaifah, D.\& Sukesi, T.W. (2015). Efektivitas Air Perasan Kulit Jeruk Manis sebagai Larvasida Nyamuk Aedes aegypti. Kesmas: National Public Health Journal, 9:3, 207.

Pilla D'Incao, M. (2012). Effect of Saponin Extracted from Passiflora alata Dryander (Passifloraceae) on development of the Spodopterafrugiperda(J.E. Smith) (Lepidoptera, Noctuidae). International Journal of Plant Research, 2:5, 151-159.

Ridha, M.R. \& Nisa, K. (2011). Larva Aedes aegypti Sudah Toleran Terhadap Temepos di Kota Banjarbaru, Kalimantan Selatan. Jurnal Vektor Dan Reservoir Penyakit, 92-109.

Ridha, M. dkk (2013). Hubungan Kondisi Lingkungan dan Kontainer dengan Keberadaan Jentik Nyamuk Aedes aegypti di Daerah Endemis Demam Berdarah Dengue di Kota Banjarbaru. Jurnal Buski, 4:3, 133-137.

World Health Organization. Guidelines for Laboratory and Field Testing of Mosquito Larvicides; $2005 . \quad$ p 1-41. Availablefrom:http://whqlibdoc.who.i nt/

WHO. (2011)Comprehensive Guidelines for Prevention and Control of Dengue and Dengue Haemorrhagic Fever. SEARO. 2011. 159-168.

WHO. (2020). Dengue and severe dengue. Availablefrom:https://www.who.int/n ews-room/factsheets/detail/dengueand-severe-dengue

Yuliasih, Y. \& Widawati, M. (2018). Aktivitas Larvasida Berbagai Pelarutpada Ekstrak Biji Kayu Besi Pantai (Pongamia pinnata) terhadap 
Care: Jurnal Ilmiah Ilmu Kesehatan Vol .8, No.2, 2020, hal 195-205

Mortalitas Larva Aedes spp. Balaba: Jurnal Litbang Pengendalian Penyakit
Bersumber Binatang Banjarnegara, 125132. 